30 年の施設の異なる放射線科医の結果判定した 80 人のフ イルム再読の結果報告を行った。評価は 5 段階方式を用 いメタル I.I. の有用性の再確認とさらに感度・特異性の 二点の差も報告したが.

簧問 (高知一楠瀬) 読影は, オープン方式かクロー ス方式か

答 ブライド方式のクロース，チェックです。

質問 (NTT一馬場) 経験の異なる読影医の感度, 特異 性は集検としてこの程度で問題はないのか，

答 経験の異なる読影医の心理的影響の差が生じ，感 度は高いが特異性にはその影響により低く出た。読影も 胃間接フィルムとなると直接撮影フィルムとも異なり経 験の豊富な人の差は当然異なるのはあり得る。演題14は， 日常の業務の中でできあがった胃間接撮影フィルムの画 像評価として二重造影を主体とした 7 体位を，造影剂附 着条件の 5 段階基準を独自に作製し，主観的評価により クラスタ分析（似た者同士）の手法により解析を行い統 計的な処理で評価を行った。演題15も二重造影を主体に した統計処理で多変量解析を行い，胃撮影した体位を良 い, 悪いの 5 段階評価をコンピュータ処理を行ったもの であった．先程の画像評価も同じような方法であるが， 胃の形態的なものを処理する場合, 機能的な変化, 器質 的変化の著しいものを一枚の写真として呼価する場合, どこまで追跡解析できるものか難しいと思われる．評価 対象, 人数, 処理時間, 評価内容, 評価基準の制定等色々 条件が整わなければならない.しかし将来は益々これら の解析手法が基準化されると思う。最後の演題16は，ス トップの表示, 示現範囲，意義の再検討として胃造影撮 影された25例を選んだものを胃モデルとして棈円の展開 図まで表示し検討した。

質問 （国立ガンセンター加藤）胃の形は色々で胃形 の検討がされていない，(国立横浜病院一斉藤）77区域・ 表示法は，病変の位置をより明確にする目的であった。

演者の論理および前提条件に無理があるように思うと の質問があった．演者馬場も25例では数が少ないので娭 討するとの意見もあった。市川らの表示によれば小弯の 幅を小弯線から前後壁側へそれぞれ $1 \mathrm{~cm}$ 計 $2 \mathrm{~cm}$ ある が演者はX線写真上の $1 \mathrm{~cm}$ をもって論理を構築された ようである. 出発点に問題があり再計算の必要があろう. 全体を通して，いずれにしても一枚一枚の胃撮影の示現 能の大切さをさらに再認識し，より満足のいく診断価値 の高いX線写真の追求をさらに重ななければならないと 思う。
増感紙一1

座長 四宮恵次（化成オプトニクス）

\section{7. 同時多層断層撮影における写真画像の特性について} 岩手県立宮古病院

○鳥居東悟・野崎泰久 岩手県立釜石病院 織笠 諴・小笠原秀利

〔目的〕同時多層断層撮影で画像を得る場合，患者に 対して被曝軽隇等の利点を持つ，しかし下層になるほど にX線の減弱が生じ当然増感紙の高感度化を図ることに なる。よって同一の増感紙で撮影できないから各層にて 画像に差がでてくる．物理的因子の值とエントロピー法 $\mathrm{ROC}$ 曲線を作成することから問題点を検討した。

〔結論〕至適電圧で值をもとめたところ下層において 鮮鋭度およびコントラストの低下に加え，スクリーンモ トルによる粒状性の悪化が検出能を悪くしている，同時 多層断層撮影で画像を得る場合，スクリーンモトルの影 響を十二分に考慮しなければならないし，またフィルム とスクリーンの一体化したシステムの追求が必要だ。

\section{8. 胸部撮影用感度補償堌感紙の試作}

国立能本病院放射線科

○荒不不次男・井芹卓兒・中野是弘

熊本大学医療技術短期大学部 東田善治

熊本大学医学部附属病院中央放射線部 洞田貫誠志

東芝横浜金属工場 中村光夫

今回われわれは，肺野のコントラストを損なうことな く肺門部, 綐隔部の描出可能な感度補償増感紙を試作し, その物理特性および臨床評価について検討した。補償領 域の形状および感度は臨床写真50例をもとに求めた、物 理特性として, 感度特性, 鮮鋭度, 粒状性, 写真コント ラストを測定した結果，高圧領域における感度特性はわ ずかで鮮鋭度，粒状性においては感度が高い緹隔部でわ ずかに低下した。また，補償フィルタ法との肺野におけ る写真コントラストの比較では, 感度補償増感紙法でコ ントラストの改善がみられた。臨床写真においても同様 に肺野のコントラストを損なうことなく肺門部, 䋛隔部 の描出にすぐれ，感度補偵増感紙法の有用性が認められ た.

19. 顔面・到部側面用感度補償増感紙の試作 藤田学園保健衛生大学病院 
○吉田龍彦・诨原孝彦・沢田武司 東芝横浜金属工場

横田和人

今回われわれは, 新部側面用およびスポット状の 2 種 類の感度補償增感紙を試作し, 補償効果ちよび臨床応用 について倹討した，方法は，吸収体にアクリル $5 \mathrm{~cm}, 8$ $\mathrm{cm}$ 厚を用いて管電圧 $50 \mathrm{kV}, 70 \mathrm{kV}$ でX線撮影を行い, 各フィルム濃度を測定して濃度分布および形状を調べた。 また試作増感紙を用い，実際にいくらかの部位について X線撮影を行った。濃度測定の結果, 最高濃度部と最低 濃度部の差法1.0以上となり, 試作增感紙注有用な補償効 果を持つことを確認した。また，その形状も試作計画時 に近いものとなった。臨床上では，頸部側面撮影におい て舌骨・前頸部の過度濃度部が改善された。スポット状 のものについても広範囲に活用できることを確認した。

20. 感度分布の異なる增感紙の臨床応用（第 2 報）

神戸大学医学部附属病院中央放射線部

○岡山貴宣・松永 登・今井方文 古東正宜・西 政美・佐古正雄 侏東芝横浜金属工場

横田和人

〔目的〕われわれは，腹部正面単純写真の情報暨を最 大限に得るため，至適な感度補償増感紙を作成した。

〔方法〕本法は通常の增感紙に黄色い色素を塗布し， その色素の量に応じて感度補償を行うものである。そこ で以下のことについて検討した. (1)感度分布の比較(2)感 度補償領域におけるX線画像の粒状性，および鮮鋭度(3) 臨床導入による情報量の評価

〔結果〕1第 1 報で求めた理想の感度分布に近い分布が 得られるようになった。(2)增感紙の乳剤層の間に色素を 塗布することにより，感度補償領域における粒状性は， 中心部に対し大差はなかった. (3)色素により, 感度補償 部の鮮鋭度は向上した. (4)臨床より, 今まで読影し得な かった側腹部の描出が可能となった。

\section{1. 胸部単純写真における濃度補償増感紙の試作}

岐皁大学医学部附属病院中央放射線部 ○岡田俊夫・武山 明・小林 博 関谷 潔・岡田仁志・岡田富貴夫 化成オプトニクス(㧣)

\section{三浦典夫}

〔目的〕胸部単純撮影において, 肺野, 肺門, 䋛隔の 三領域を良好なコントラストでかつ画質の低下をもたら すことなく描出するために, 增感紙の感度を三領域で補 償した胸部単純補偵增感紙を試作し検討した。
〔結果〕堂光体な $\mathrm{CaWO}$ としてイエローの色素染色 で感度補償した。補償領域は岐阜大学方式とした。領域 別感度比は，FSに対し肺野85肺門200繸隔300とした。各 領域の MTF. RMS は, 肺野部でFSに対しすぐれてい た．增感紙による補偵法であるから従来の撮影手技と変 わらず簡便で, 肺野の画質を低下さすことなく一枚のフ イルム上に肺野, 肺門,・䋛隔が描出できた。

\section{2. 感度補償型増感紙を使用した胸部写真の検討}

山口大学医学部附属病院放射線部

○上田克彦・大塚昭義・橋田昌弘 山内秀一・岡山昭雄・迎 英紀

横山敬・中西 敬

胸部撮影では肺野と綐隔の被写体コントラストが高い ため高圧撮影などが行われている．当院ではすでに補償 フィルタによる胸部撮影を行っているがより簡便て肺野 のコントラストの低下しない感度補償型增感紙を使用し 胸部撮影を行いその有用性を検討した。

390 症例における高压単純写真と感度補償写真を読影 し気管支，緃隔部等の陰影の描出能を評定し比較した。 感度補償写真は高圧単純写真と比較すると50\%以上の 向上が見られた。また肺野のコントラストの低下なしで 縦隔部の濃度を上げることができ，撮影に手間がかから ないという長所を持っている。

\section{座長集約}

本セッションは增感紙一川の基礎的な内容と異なり, 蹦床応用的なものが殆んどである。その内容を概説する と演題17は, 同時多層撮影における各層の画筫を, 物理 的因子とエントロピーおよびROC曲線の対比において 挨討し，下層における増感紙とフィルムの一体化した追 究が必要であると報告した。

演題18は, 胸部補償增感紙を試作し，その物性および 臨床評価を補償フィルタ法との比較において行い, 増感 紙法が肺野のコントラストを損うことなく，肺門，綐隔 部の描出が優れていると追加スライドを用い報告した。

(子稿訂正, Fig 5 横軸 $\mathrm{mm} \rightarrow \mathrm{cm}$ )

演題19は, 顔面, 頸部側面用補償增感紙を試作し, 取 级性を含奻たその有用性について報告した。

演題20は, 腹部専用の補償増感紙に関するもので, 昨 年より改良した試作増感紙について, 理想的な感度分布 に近い濃度分布が得られるようになったと報告した。

演題21は，18と同様に試作した胸部用補償増感紙の有 用性について報告した。(予稿訂正，図 3 中， $\mathrm{A}$ を( $\mathrm{A}+$ $\mathrm{A}), \mathrm{B}(\mathrm{A}+\mathrm{B}), \mathrm{C}$ を $(\mathrm{B}+\mathrm{B})$ に，また図 $5 \mathrm{a}$ は 印刷時の現出不足による) 